Les actes de colloques du musée du quai Branly Jacques Chirac

$2 \mid 2009$

Performance, art et anthropologie

\title{
Présentation du film Comancheria
}

\section{Marthe Thorshaug}

\section{(2) OpenEdition}

\section{Journals}

Electronic version

URL: http://journals.openedition.org/actesbranly/432

DOI: 10.4000/actesbranly.432

ISSN: 2105-2735

\section{Publisher}

Musée du quai Branly Jacques Chirac

Electronic reference

Marthe Thorshaug, "Présentation du film Comancheria », Les actes de colloques du musée du quai Branly Jacques Chirac [Online], 2 | 2009, Online since 17 December 2009, connection on 08 September 2020. URL : http://journals.openedition.org/actesbranly/432 ; DOI : https://doi.org/10.4000/ actesbranly.432

This text was automatically generated on 8 September 2020

(c) Tous droits réservés 


\title{
Présentation du film Comancheria
}

\author{
Marthe Thorshaug
}

1 My background is artistic and I graduated from the academy of fine arts in Oslo in 2003. In 2006 I made a 30 minutes film in Oklahoma titled "Comancheria ». It is about a group of Comanches who are preparing for a sweat lodge, which is a common sauna ritual among the Plaine Tribes. The film is divided into chapters; one for each ingredient needed to carry out a sweat lodge:it is Rock, Water, Cider, Wood and Fire. By the way the film is a low budget production, written, directed, filmed and edited by me. It was first screened at the photo gallery in Oslo in 2007 and last year it was screened three times during the annual one day long Comanche film festival in Oklahoma. 
Comanche Moon, 2007.

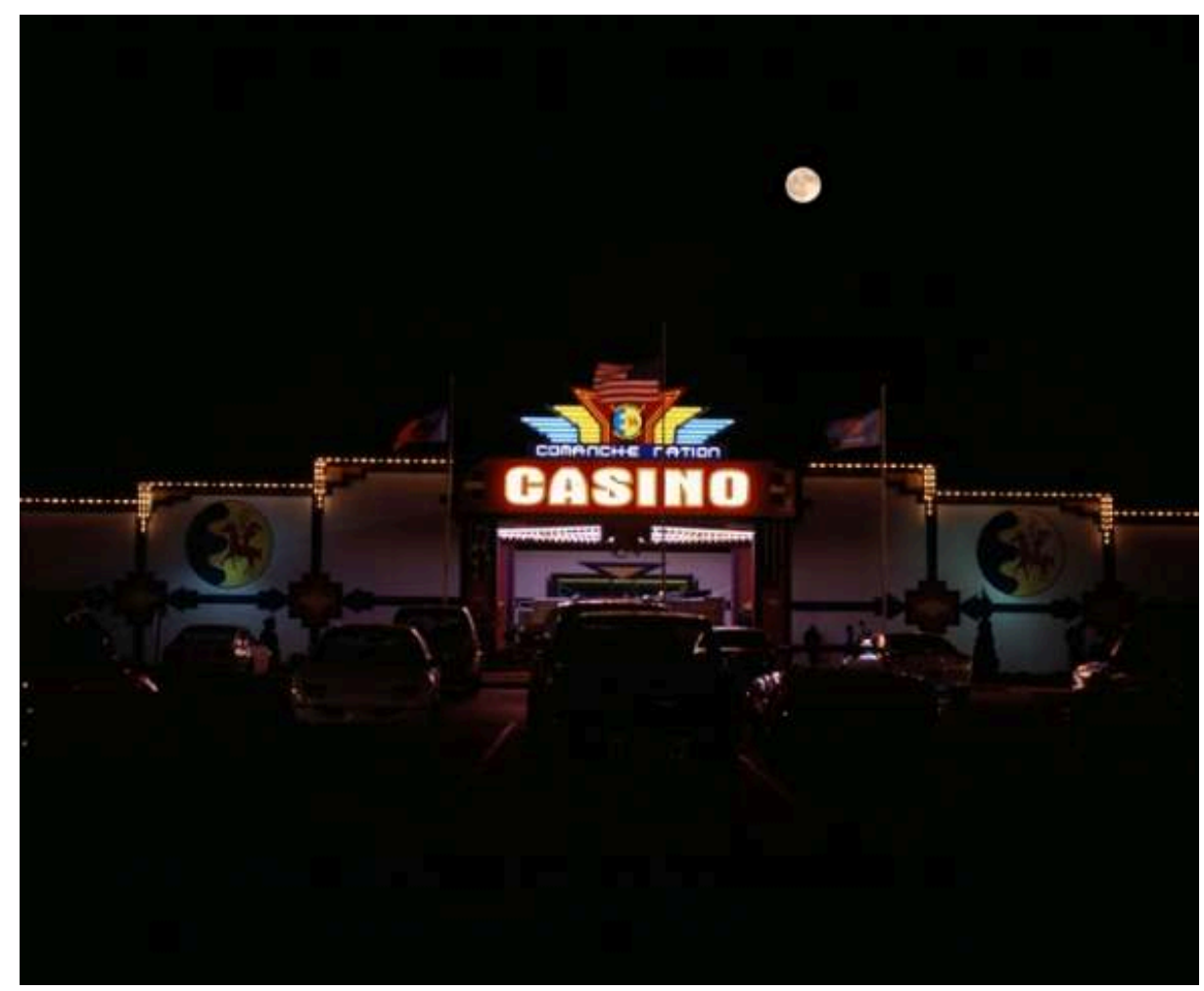

Photo Marthe Thorshaug

2 Back to the year 2002 I was working in a tiny "Queen Center" in the middle of nowhere in Texas. This was during the time of the year when Texas is really hot so I spent most of the time in my air-con trailer. Luckily my good Texan friend, Jim Janeway, lent me his favorite book titled "The Comanches - The destruction of a people", written by T.R. Ferenbach. This friend of mine who also happened have the business card of Wallace Coffee, the chairman of the Comanche nation that he incidentally met at a rodeo up in Forth-Worth good in the year and my friend thought that the card might be handy one day. After a while the plan was hatched. I had a video camera and Jim had his business card for the chairman of the Comanche nation. The next year I was back in Texas with a camera. Jim and I drove up to Oklahoma, to headquarter of the Comanche nation. In the chairman's office I was introduced as a documentarist from Norway who was overwhelmingly interested in making a film about the Comanche. At that point I felt like a social anthropologist from hell. But the welcome was very nice and the chairman took me on tour in his car and he showed me all the institution they have and the progress the Comanches are making today. He also introduced to an enormous amount of people at the annual Comanche Elder Day. There suddenly a person tapped on my shoulder and asked : "you want to come and sweat tonight?". In that sweat lodge I admit most of the characters who acted in the film. This is where the trickster comes in. The trickster is a universal character in mythology, religion and fairy tales. Among the tribes of the southern Plains to the coyote, or the trickster dog, is the most common character. But the trickster can take all kinds of shapes and because of the camouflage you can never know who the trickster might be. Often the trickster even appears as the nicest guy offering to help you. Then, there is the second ambiguity concerning the trickster. Because one can really not know what the trickster is up to. Sometimes he 
can fool you badly, but can also do you to the path of fortune. So, in general it is always a risk to go with a trickster. And to blur it even more the art scene is a tricky context because things can very easily turn out as the opposite of your intention.

The Chief, 2007.

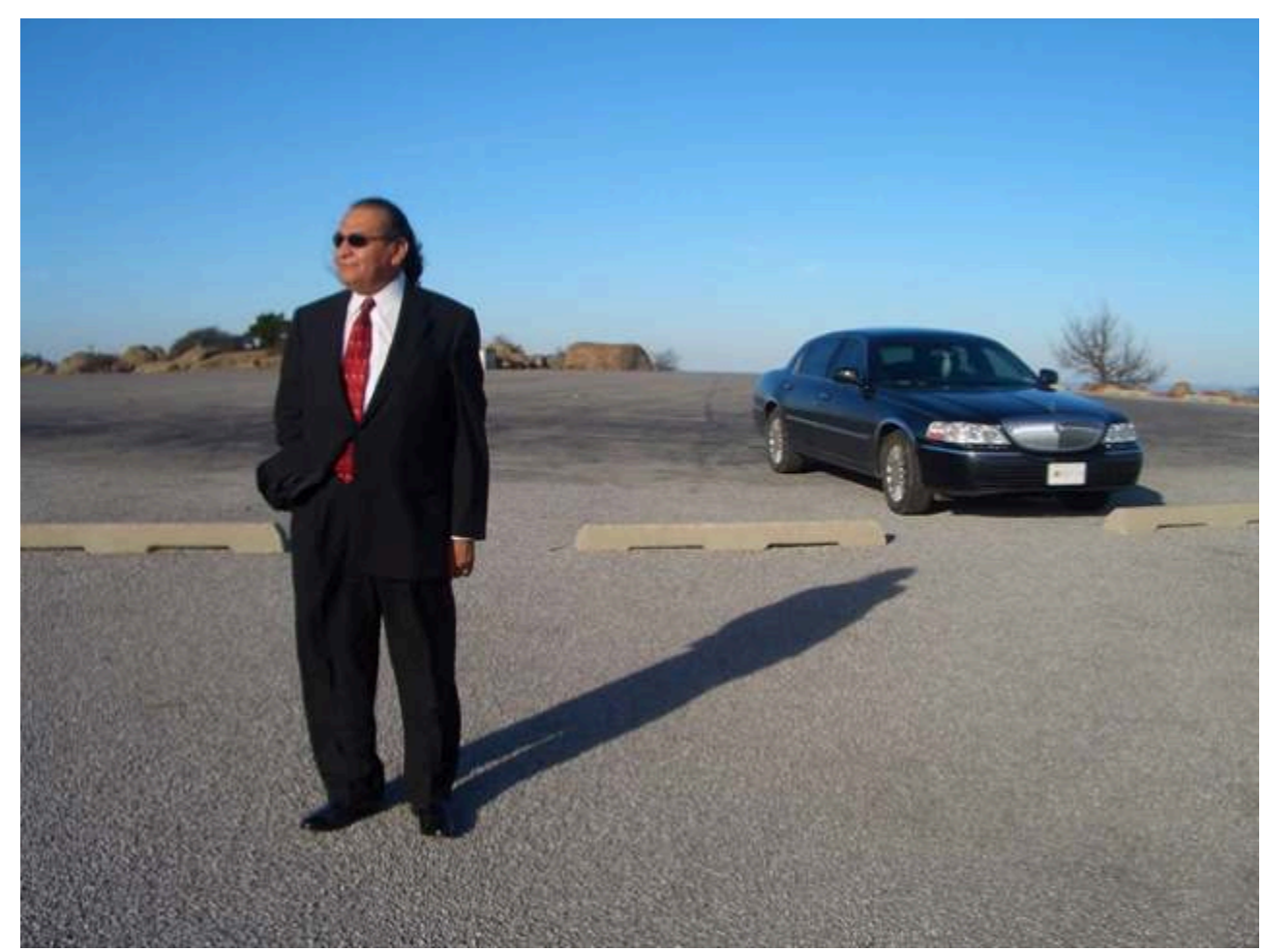

Photo Marthe Thorshaug

3 Anyway, after that sweat I still had no idea what I was doing in Lowtown, Oklahoma. Nevertheless, the next year I was back in Oklahoma with the purpose of visiting my new friends on a subsidized research trip. Back in Norway I suddenly had a vision: I was going to make a fictional road movie through a modern Comancheria with a touch of reality so that one can feel that the Comanches are again expanding on the American heartland. Six-month later I was back and luckily my friends were happy to be cast for this film. 


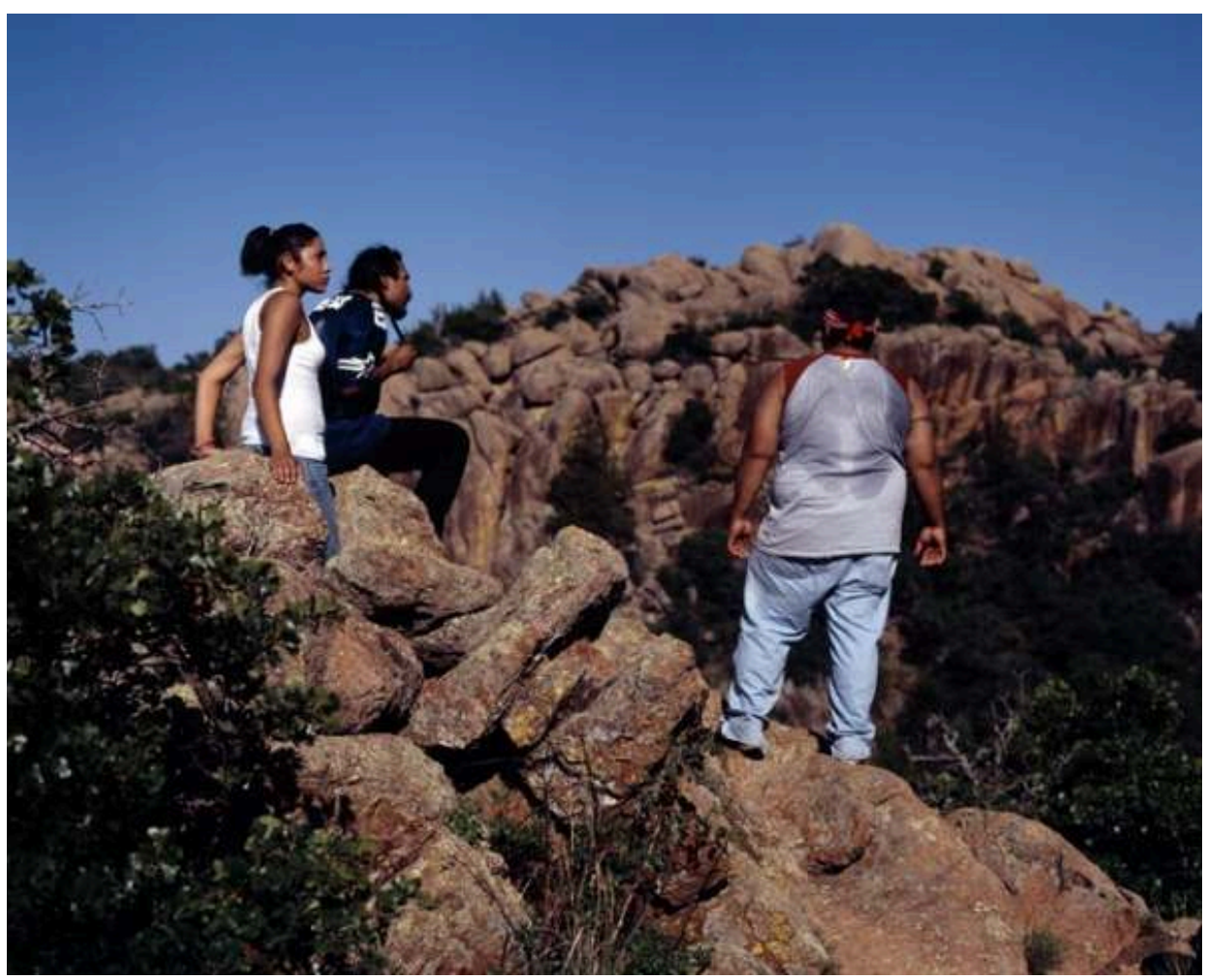

Photo Marthe Thorshaug

4 The Comanche country is the frontier between fact, fiction, propaganda and myth: Buffalo Bills wild West show, later the Western and now the road movie where invented in this area. All the geographical names are familiar to us. In this landscape reality is just a visual effect. The real is reduced to a shaky hand held camera with a bad sound. By blurring the boundaries between fact and fiction the appearance of a new Comancheria comes forth. In the end it is all about catching a certain spirit.

\section{Discussion}

5 Richard Schechner: Concerning your film, that I appreciate very much, I like the way anthropological films have changed. You explained that the film formed you because the chief standing outside was linking and it was both sustaining him and destroying him. Why didn't you pursue further the cowboy, because he is also an extremely ambiguous figure? The second even more important question is: you are absent. You need to go back and give them a camera filming you, because you are the profound trickster in this. You only make two appearances: you appear as the skull at the very beginning. That's where it shivered up my spine, because I knew it is a plant. And even if there is a skull line on the side of the highway, I was just good to be true. And the second place where you appear is were the buffalo were only a few of them and then became many of them, which is a kind of synecdoche for the people themselves who are returning. The buffaloes were supposed to be exterminated and then they start to come back, and they need a lot of land. Well, these Comanches were exterminated and they are coming back. I so liked it, I wish you were in it to further complicate it and I wish that we hear more of the cowboy, and I wonder why we didn't. 
6 Marthe Thorshaug: I start with the cowboy. He is just one of the characters they meet along the road. This is all like a travelogue in a Comancheria, in a mental Comancheria that might come, some day.It's a historical territory. And by the way they meet this trickster dog and they meet also a buffalo wrangler who explains about the buffalo stock. So there are more buffaloes in the film. They also meet the Comanche police, just briefly, passing by on the road. The brief talking head whit him and the cowboy. It is a lot of things I just left there, in the air, and doing that I was very much inspired by the Comanche stories which is very much like that: kind of pointless stories, stopping in middle with no really trench line or open conclusion. So there are just a lot of props, and you have to put it together yourself and to make your own story. As a matter of fact I am acting in the film, as a character, as everybody else. I am the "seeking visitor", I am in the swimming pool while the snake is sneaking up to me. I wanted to include the "seeking visitor" because in order maybe to underline their impossibility to get into the Comanche culture and also to underline their strength in this simple ritual, they have and we don't have. We can swim in the sauna and go to the casino instead, and give our money to the Comanche Nation. And who is shitting who becomes an open question. Maybe I made my own trap.

7 Public: I think that your movie is about ritual and more precisely a ritual in 2009 anthropology. What you actually present is a ritual that is changing time after time and I liked it. That's still into their culture. But at the same time change and ritual are not opposed. And at the same time you got some anthropological point of view as you got different parts of the ritual and you show us this. You don't show us the ritual itself, but you show what is before the ritual, where the wood comes from, where the water comes from and all this in a very anthropological way. If you would understand how the ritual is in 2009 you need to know how they do prepare this ritual. So I really liked it, and at the same time, you are not an anthropologist and you do not pretend to be one. You mentioned Al Foster, who is talking about the ethnographic desire of the artist and the artistic desire of the anthropologist.

8 Marthe Thorshaug: Just a short comment on that. One of the medicine man in the Comanche Nation liked it tough and claimed it to be a real Comanche film. At the same time he was suspicious about taking something sacred, even though the sweat lodge is a much more daily ritual. He said "even though, you take something sacred and you are going to make a funny road movie out of it", but I am just giving the ingredients, not the recipe.

Public: First of all, I liked the film. My own fieldwork is on Indian American visual production, films and contemporary arts in mainly the Midwest. My question was in relation to your collaboration with the group. American Indians have a huge visual production, film production, collective action going on especially in the Midwest, and in the South. Most of them collaborate with foreign artists and foreign anthropologists despite the fact that they want to cut ties with what they would call the "hegemonic' or "Western" representation process. I was interested in what is your collaboration process with them and do you feel that this film served their interest at all? Most of visual production, and especially film made by American Indians, are for social visibility in light of social invisibility. How did your collaboration serve them also, and how were you accepted through that?

10 Marthe Thorshaug: The people I collaborated with are the people I met in that sweat lodge. Basically, and it this far from the people I was recommended by the Comanche 
Nation to visit at the beginning. So it's more like a result of friendship or people you meet along the road that you can catch up with. But I am aware that there is also a film production among the Comanche nation, but I haven't collaborated with any other filmmaker there. itself; so in depends on who are the people you meet. As far as the cowboy is concerned, I did not meet him until I was starting to shoot. Sometimes the dialogue is written, sometimes there is a keyword, sometimes just documentary filming. I don't know the boundaries anymore.

The Snake, 2007.

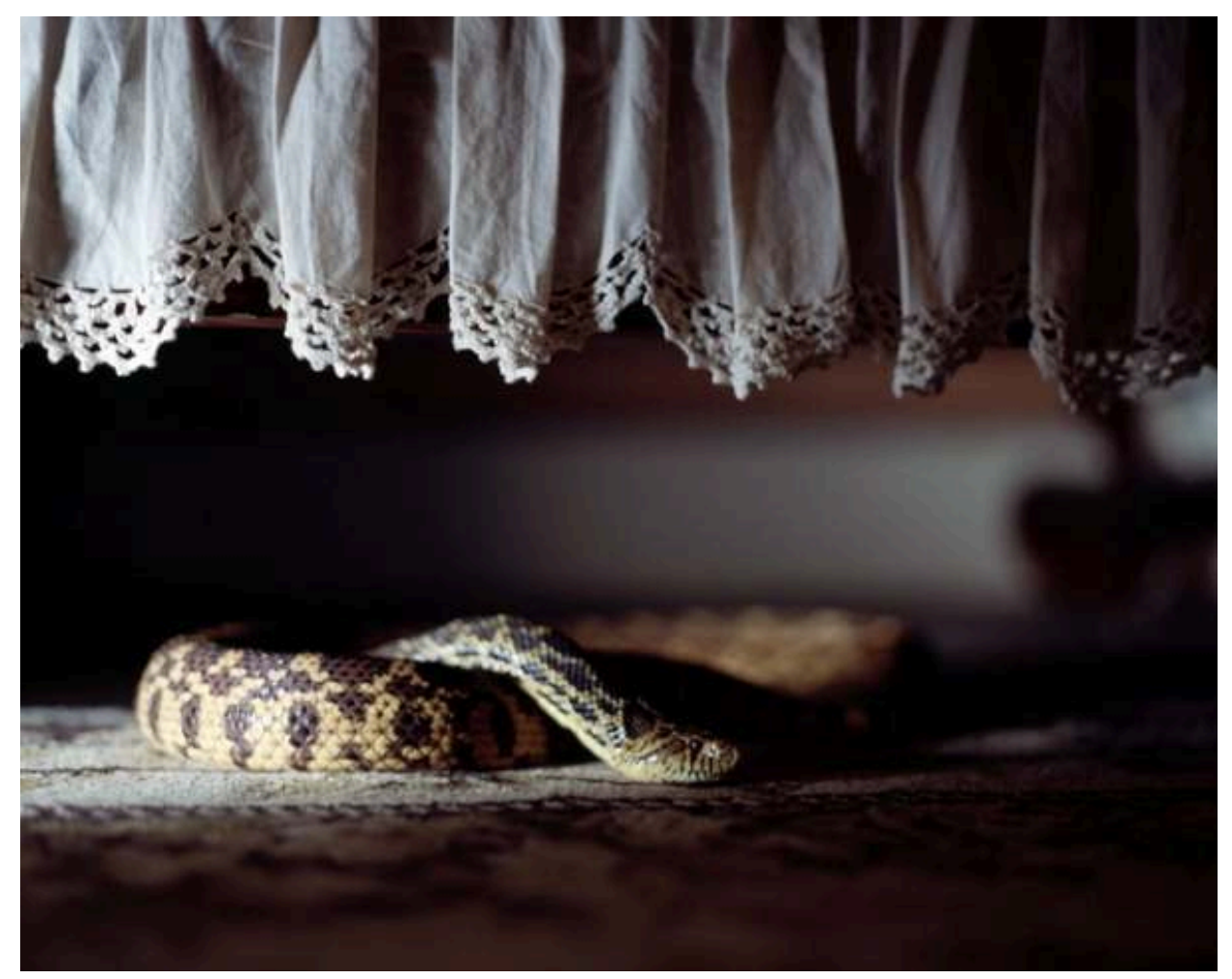

Photo Marthe Thorshaug

Les actes de colloques du musée du quai Branly Jacques Chirac, 2 | 2009 


\section{ABSTRACTS}

Norwegian artist Marthe Thorshaug will show extracts from her film Comancheria, a 'road movie' starring the Comanche Indians in Oklahoma, USA. Thorshaug will talk about the film and about the artist as 'trickster.'

L'artiste norvégienne Marthe Thorshaug montre des extraits de son film Comancheria, road movie sur les Indiens comanche vivant en Oklahoma (USA). Cette projection est pour elle une tentative d'attribuer à l'artiste le statut de «trickster ».

\section{AUTHOR}

\section{MARTHE THORSHAUG}

Marthe Thorshaug est artiste. Elle vit et travaille en Norvège. Ses films et ses photographies s'inspirent tant de la réalité que de la fiction. 